\title{
Academy approves, critics still cry foul
}

\section{Washington}

THE current procedure for comparing DNA fingerprints is "fundamentally sound" and should be considered reliable when done properly, according to a report released this week by the National Academy of Sciences' National Research Council (NRC). But while the report should make the controversial technique more acceptable in the courtroom, it is not expected to end debate about its use.

The report* suggests additional studies and measures to improve the standards of laboratories that carry out the tests and to strengthen the statistical basis for making comparisons of DNA samples. The NRC panel recommended that researchers take DNA samples from 100 people in each of 15 to 20 ethnic groups and that they maintain a database of the blood samples to reduce the possibility that ethnic subgroups in populations can distort the chances of finding random matches. It also recommended that the US Department of Health and Human Services establish an accreditation programme to check the quality of forensic laboratories.

None of these suggestions are contentious. But its chapter on population genetics seems likely to renew debate over whether the technique is a good way to identify someone conclusively.

The US Federal Bureau of Investigation (FBI) and many prosecutors have used a 'multiplication rule' to determine the odds of random matches. Using that technique, a laboratory comparing DNA samples at several locations on the chromosome would multiply together the known frequency of each DNA site in available databases. Critics, however, argue that this technique discounts the possibility that the patterns may be related and inherited together. But in the absence of extensive databases on ethnic subpopulations, researchers do not know which patterns are typically inherited together.

The NRC report compares the multiplication rule to multiplying the odds of finding someone with blond hair by the odds of finding someone with blue eyes to determine the odds of finding someone with blond hair and blue eyes. That approach is misleading, of course, because blond hair and blue eyes are related; the actual odds of finding them together are much higher. The report cites one occasion in which the multiplication method was compared with an actual counting of matches in the database: the first predicted the odds of a match at 1 in 739,000 million, while the second showed the real odds to be 1 in 500 .

The NRC report calls for more samples and better databases to reduce reliance on statistical crutches such as the multiplication rule. But it cautiously endorses the use of a modified multiplication method, using the lowest observed odds for each DNA site.

This compromise, say critics, is just what the DNA fingerprinting advocates wanted. While agreeing with the NRC recommendations on additional measures, the critics claim that the NRC panel acceded to pressure from the US Department of Justice and the FBI, two sponsors of the report. They allege that FBI scientists, to whom a draft copy of the report was leaked last year, convinced the panel that it should delete portions of the population genetics chapter that would have made DNA fingerprinting evidence more difficult to use in court.

Earlier this month, a judge in Seattle, Washington, ordered a copy of the earlier draft of the report released as part of a case (State $v$. Copeland) in which DNA fingerprinting evidence was being challenged. There are substantial changes between the draft (dated 15 October 1991) and the final report, mostly in favour of the use of DNA fingerprinting in court.

In particular, the draft does not recommend the use of the multiplication rule. Instead, it warns that "neglecting population substructure plays the same role in genetics textbooks as neglecting friction and air resistance in physics textbooks."
But by eventually accepting the use of a modified multiplication method (even reluctantly and temporarily), that is exactly what the NRC panel has done, says Peter Neufeld, a lawyer who has fought the forensic use of DNA fingerprinting in several court cases.

Victor McKusick, a geneticist at Johns Hopkins University who chaired the NRC panel, acknowledges that John Hicks, an FBI scientist, submitted a lengthy criticism of the population genetics chapter to the panel. But the main changes in the final version "came out of the review process, not Hicks' letter," he says. As a sponsor, the FBI is not supposed to dictate the final product. But it is not inappropriate for FBI scientists to offer expert advice, he says. (In fact, the preface to the report thanks Hicks for his assistance.) "It is, however, unfortunate that the draft got such wide distribution," McKusick adds.

The controversy over the population genetics is unlikely to die with the release of the report. But McKusick hopes that the recommended research on ethnic subpopulations will ease some of the concerns about the multiplication method, if not the suspicion of political meddling in NRC reports. Christopher Anderson

* DNA Technology in Forensic Science, National Research Council, 1992.

\section{Mixed Arctic results}

\section{London}

EUROPEAN scientists measuring the amount of ozone in the stratosphere above the Arctic face a situation in which less is more. While their data show a decline in the thickness of the ozone layer from last year to this, the drop is less than had been predicted last autumn by US scientists using different methods. The result is a mixed message to the public, and a reminder that scientists still have much to learn about the factors that influence stratospheric ozone depletion.

The European Arctic Stratospheric Ozone Experiment (EASOE), which ran from November until March, was designed to swell scant knowledge of the atmospheric dynamics of the north polar regions. The preliminary results showed a complex situation, with ozone loss from halons aggravated by the aerosols from the eruption last summer of Mount Pinatubo and the huge high-pressure system that has lurked over Europe for much of the winter. The effect worsens over the winter and dissipates once spring arrives.

A team of scientists have so far found decreases from historical levels of between 10 and 20 per cent in stratospheric ozone. Although that is greater than ex- pected, it falls short of predictions by a team of scientists at the US National Aeronautics and Space Administration of declines approaching 40 per cent. That estimate was a 'worst case', with all the active chlorine measured in the atmosphere over the Northern Hemisphere being involved in ozone depletion.

Less work has been done on Arctic ozone than on the situation over the Antarctic, where a hole was discovered in the mid-1980s. And the differing meteorology at the two poles makes comparisons difficult. A tight polar vortex in the Antarctic produces sustained low temperatures and inhibits the exchange of air, whereas the Arctic has a looser and warmer vortex. The EASOE team hopes to learn much more about polar dynamics and the behaviour of active chlorine in the next few months as it analyses the data.

The experiment covered a wide area stretching from central Europe, across the North Atlantic to Greenland and the Russian Arctic, and involved more researchers, working for a longer time on more experiments, than ever before. "The collaborative nature of the campaign was very successful", says the project's coordinator, Neil Harris. 